\title{
Use of glycosides extracted from the fique (Furcraea sp.) in wastewater treatment for textile industry
}

\author{
W. A. Lozano-Rivas ${ }^{1}$ K. E. Whiting ${ }^{2}$ C. Gómez-Lahoz ${ }^{3} \cdot$ J. M. Rodríguez-Maroto ${ }^{3}$
}

Received: 25 August 2015/Revised: 15 December 2015/Accepted: 8 February 2016/Published online: 24 February 2016

(C) Islamic Azad University (IAU) 2016

\begin{abstract}
The laboratory tests for the use of sapogenic amphiphilic glycosides as a coagulation-flocculation aid are presented in this paper. These amphiphilic glycosides were obtained, through a natural fermentation process, of the juice, of fique (Furcraea sp.) leaves. Decantation allows for the separation of a supernatant denominated "supernatant fique juice" and a decanted fraction denominated "decanted fique juice." The latter contains most of the sapogenic amphiphilic glycosides and was mixed with the chemical coagulant ferric chloride hexahydrate, at varying doses. Ferric chloride hexahydrate was also used as a control to ascertain the removal efficiency of persistent contaminants from samples of a textile industry effluent. The parameters of interest were typical indicators of water quality such as color, turbidity, chemical oxygen demand, $\mathrm{pH}$ and conductivity. The results indicate that the decanted fique juice, when used as a coagulationflocculation aid, and upon comparison with the chemical coagulant alone, causes an additional color and turbidity reduction of 31 and $17 \%$, respectively. No significant differences were noted in the chemical oxygen demand values $(\alpha=0.05 ; P<0.001)$. Thus, there is a scope for further research about the commercial feasibility of DFJ as an industrial water treatment agent, which reduces the toxicity of raw fique juice and its detrimental environmental effects.
\end{abstract}

W. A. Lozano-Rivas

wlozanorivas@gmail.com

1 School of Environmental Sciences, Research Group on Environment and Sustainability (GUIAS), Piloto of Colombia University, 110231 Bogotá, D.C., Colombia

2 Engineering Faculty, Universidad EAN, Bogotá, D.C., Colombia

3 Chemical Engineering Department, University of Malaga, 29071 Malaga, Spain
Keywords Coagulation - Flocculation aid ·

Textile industry - Agricultural waste valorization .

Treatability tests

\section{Introduction}

The textile industry generates a complex mixture of polluting substances, ranging from residual dyestuffs to heavy metals associated with the dyeing and printing process (Correia et al. 1994; Hood 1997; Soares et al. 2006; Sungur and Gülmez 2015). The presence of dyes makes wastewater treatment difficult for the traditional techniques. The removal of dyes by physical (Golob et al. 2005), chemical (Rajkumar and Kim 2006) and even biological (Zheng and Liu 2006) means is widely reported. Such techniques are incapable of causing complete degradation, and this can generate toxic by-products; some dyes are resistant to biodegradation, for example, because of their biotoxicity coupled with a possible mutagenic and carcinogenic effect (Gong et al. 2008). In all cases, an additional complication is the fact that the exact color and chemical composition of textile effluents are subject to daily and seasonal variations, due to the nature of the industry (Soares et al. 2006; Tafesse et al., 2015).

A potential solution to the above issues is the use of natural flocculants or substances which aid flocculation. These are particularly beneficial from an environmental stance because they are both biodegradable and renewable (Khiari et al. 2010, Saritha et al. 2015, Meraz et al. 2016).

In this paper, using Bogotá, Colombia's textile industry as a case study, and specifically wastewater samples collected from the dyeing process, the contaminant removal efficiency of the aqueous fraction or "juice" extracted from 
the leaf of the fique plant (Furcraea sp.) is evaluated. This juice, which is expected to act as a coagulation-flocculation agent, was obtained via a natural fermentation/decantation process, which resulted in two fractions, a supernatant (referred to as SFJ, herein) and a decanted fermented juice (DFJ).

Fique (Furcraea sp.) is a fibrous monocot that grows in various parts of the tropical Americas. Its range extends from the south of Mexico to Brazil. It is also found in Colombia and Venezuela (Casierra-Posada et al. 2006). Belonging to the family Agavaceae, the principal genera are Agave and Furcraea, which are also the most representative members (Fig. 1).

In Colombia, the predominant genus is Furcraea, of which there are approximately 20 species. These grow spontaneously throughout the country and are commercially cultivated in the tropical Andean zones (Martínez and Pacheco 2006). Colombia produces around 19,000 tons of fique per year; in 1994, the registered hectares were 15388, a figure which had decreased to 15145 by 2013 (FINAGRO 2013). Fique has been used over the centuries as a source of fiber in America. This fiber, known in Colombia as cabuya, is still used in the twenty-first century for potato and coffee packaging, and for the creation of craft products. Yet, and despite the relative importance of cabuya, the cultivation of Furcraea has had poor financial returns. It is hoped that it can become more profitable due to its increasing recognition as a product that carries various environmental benefits (Ministry of Environment, Housing and Territorial Development-Colombia; CADEFIQUE 2006; Universidad Jorge Tadeo Lozano and FENALFIQUE 2014). Its use as a biosorbent has also been explored (Agudelo et al. 2015).

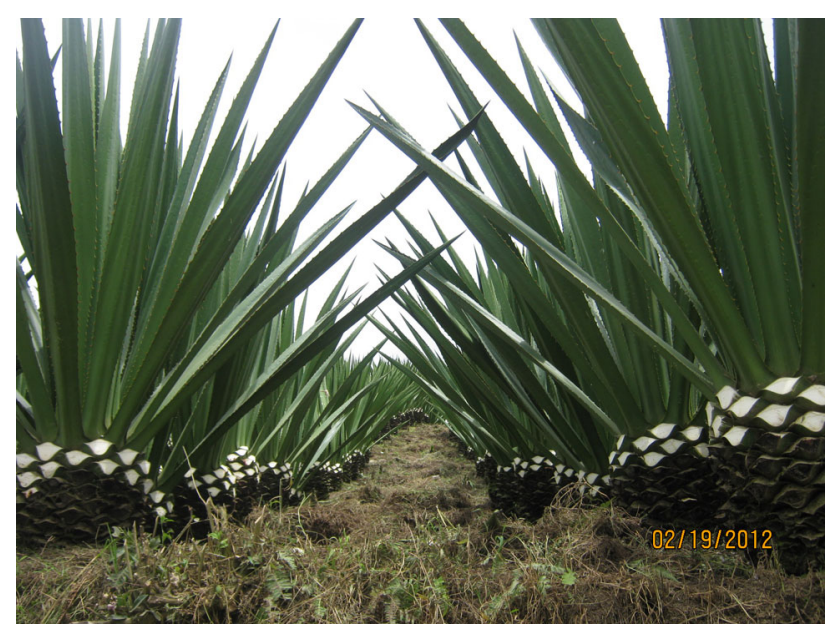

Fig. 1 Fique (Furcraea sp.). Source: http://eltambo-narino.gov.co
The fique cabuya fiber represents approximately $5 \%$ of the entire plant's weight. The majority of the remainder corresponds to the aqueous fraction, or juice, $(70 \%)$, the tow and the bagasse $(25 \%)$. All these components are currently treated as a waste of no economic value (Arroyave and Velázquez 2001; Lozano-Rivas 2012). This is not the only problem, given that in the leaf shredding process (Fig. 2), undertaken to obtain the cabuya fiber, the juice, with its toxic properties, is cast aside and left to enter surrounding water bodies or soil. This practice can thus endanger the health and well-being of fish and other aquatic organisms (Iannacone et al. 2013a, b).

The exact nature of fique juice depends on various factors including the age of the plant, the season and the soil in which it grows. Its color is typically green ocher and it has a strong smell. Density is around $1.02 \mathrm{~kg} / \mathrm{L}$, while $\mathrm{pH}$ varies between 4 and 5. It is $85 \%$ water, $6 \%$ cellulose, (D-glucose), while the remaining $9 \%$ corresponds to a mixture of sucrose, protein compounds, steroids, minerals, saponins and sapogenins (Ministry of Environment, Housing and Territorial DevelopmentColombia; CADEFIQUE 2006).

The saponins and sapogenins, along with other amphiphilic glycosides, act as biodegradable surfactants that, when dissolved in water, reduce the surface tension and emulsify fats and oils (Duque and González 1999). This paper presents an evaluation of the possible valorization of these residues, under laboratory conditions, as enhancers of the performance of the wastewater treatment plants of the fabric dye industry. The research was conducted between 2013 and 2014 at the Chemical and Environmental Analysis Laboratory of the Piloto de Colombia University in Bogota, Colombia.

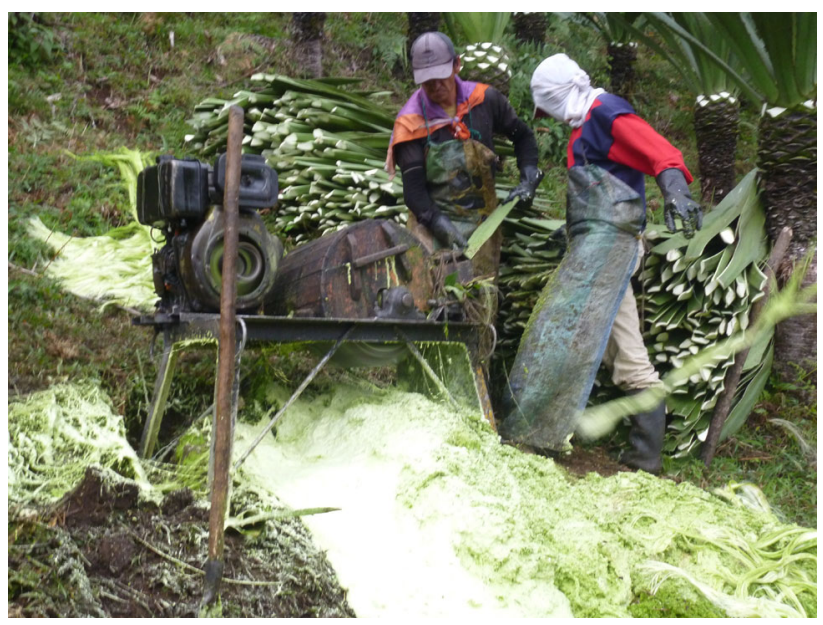

Fig. 2 Shredding of fique leaves. Source: http://eltambo-narino.gov. co 


\section{Materials and methods}

The capacity of DFJ as a coagulation-flocculation aid is evaluated using wastewater samples obtained from Bogota DC, Colombian-based companies operating in the textile sector and involved in the fabric dyeing process. In total, 90 treatability tests were carried out, distributed in 15 series. Each series underwent six tests, in order to evaluate any changes in the sample's physicochemical properties. First, the optimal dosage of chemical coagulant was determined, and subsequently, these results were compared with those obtained using different concentrations of DFJ, in addition to the chemical coagulant.

Extraction, characterization and fermentation of the fique leaf juice To obtain juice from the variety known in Colombia as "uña de águila," the leaves were minced into smaller pieces which were subsequently introduced into a beater for $60 \mathrm{~s}$. Next, they were passed through a food mill, and the resultant was filtered. All such operations were executed under aseptic conditions. The resulting juice was then allowed to ferment in a separation funnel for 5 days. The temperature was kept constant at $20^{\circ} \mathrm{C}$ (Binder, model BD53UL).

After incubation, a decanted fraction was obtained with most of the amphiphilic glycosides represented in the genins (mono and di-glycosides). The fatty acids meanwhile are present in the supernatant liquid (denominated SFJ). The fermentation process takes place with a COD removal of more than $80 \%$ in both fractions (DFJ and SFJ) with respect to the raw juice, which is an important environmental benefit of the process (Lozano-Rivas 2011). The fermented DFJ has a pH value of 4.9, a COD of $15,400 \mathrm{mg} /$ $\mathrm{L}$ and a conductivity value of $2.32 \mathrm{mS} / \mathrm{cm}$.

Analysis and Instrumentation The main parameters considered were $\mathrm{pH}$, temperature $\left({ }^{\circ} \mathrm{C}\right)$, turbidity (NTU), color (PCU), conductivity $(\mathrm{mS} / \mathrm{cm})$ and chemical oxygen demand (COD) $(\mathrm{mg} / \mathrm{L})$. The measuring instruments are given in Table 1 . The treatability tests were undertaken in six jars plus one for control (Jar-Tester, E\&Q, model F6300).

Coagulant preparation and dosage The coagulant agent employed was ferric chloride hexahydrate $\left(\mathrm{FeCl}_{3} \cdot 6 \mathrm{H}_{2} \mathrm{O}\right)$, Ph Eur Scharlau HIO336. It was chosen due to the higher efficiency of iron salts, as compared to those of aluminum, when it comes to the removal of persistent organic material, (Tatsi et al. 2003; Rivas et al. 2004; Monje-Ramirez and Orta de Velásquez 2004; Ntampou et al. 2006). The coagulant solutions $(100 \mathrm{~g} / \mathrm{L})$ were prepared with distilled water in $250-\mathrm{mL}$ graduated flasks. Dosage was based on the preliminary tests of similar wastewater samples from the food industry, as described previously in Lozano-Rivas (2011).

Determining the optimal coagulant dosage Each one of the treatability tests was performed three times in beakers (Jar-Tester). Table 2 shows the various times and speeds for each of the three stages (Longsdon $G$ et al. 1999). Samples were taken from each beaker at $2 \mathrm{~cm}$ from the surface as explained previously in Lozano-Rivas (2012). Among the different variables that were followed, the reduction of turbidity and color were the parameters selected to obtain the optimum dosage of coagulants.

Determination of the optimal dosage of the DFJ as a coagulation-flocculation aid A new series of beakers with wastewater samples were prepared. In each, the optimal dose of ferric chloride was added, with various doses of DFJ, as a coagulation-flocculation aid. The amount of DFJ placed in each beaker was between 0.5 and $50 \%$, with respect to the coagulant dose. The coagulation-flocculation aid was prepared in $250-\mathrm{mL}$ flasks at a $10 \mathrm{~g} / \mathrm{L}$ concentration. At the end of each treatability test, supernatant samples were taken at $2 \mathrm{~cm}$ from the surface as done previously in Lozano-Rivas (2012). The same parameters described in the previous section were determined.

A comparative analysis of the chemical coagulant (alone) effect and the chemical coagulant mixed with DFJ, as coagulation-flocculation aid Again, samples were taken for the evaluation of the performance of the chemical coagulant and the chemical coagulant mixed with DFJ. The optimal chemical coagulant dose was poured into three beakers and the mixture of coagulant with DFJ poured into three others as previously explained in Lozano-Rivas (2012). Once more, the same parameters were determined in order to measure the relative reduction in contamination.

Data analysis The results obtained were analyzed via the $t$ test $(\alpha=0.05)$ and the Mann-Whitney $U$. The Kolmogorov-Smirnov test $(P<0.05)$ was applied for those
Table 1 Research variables and measuring instruments

\begin{tabular}{lll}
\hline Variable and unit & Measuring instrument & Accuracy \\
\hline Temperature $\left({ }^{\circ} \mathrm{C}\right)$ & pH-meter Hanna HI2210 & $\pm 0.5{ }^{\circ} \mathrm{C}$ \\
$\mathrm{pH}$ & $\mathrm{pH}$-meter Hanna HI2210 & \pm 0.01 \\
Conductivity & Hanna Watercheck 1 & $\pm 0.0008 \mathrm{mS} / \mathrm{cm}$ \\
Turbidity (NTU) & Turbidity Meter Hanna HI93703 & $\pm 0.5 \mathrm{NTU}$ \\
Color (PCU) & Colorímeter Hanna HI93727 & $\pm 10 \mathrm{PCU}$ \\
COD $(\mathrm{mg} / \mathrm{L})$ & Photometer Hanna HI83099 (Method EPA 410.4-Adapted) & $\pm 22 \mathrm{mg} / \mathrm{L}$ \\
\hline
\end{tabular}


Table 2 Mixing velocities and times for each stage of the treatability tests

\begin{tabular}{lccc}
\hline Stage & Mixing speed (RPM) & Gradient $\left(\mathrm{s}^{-1}\right)$ & Time $(\mathrm{min})$ \\
\hline Fast mix & 300 & 320 & 1 \\
Slow mix & 60 & 66 & 20 \\
Sedimentation & 0 & 0 & 30 \\
\hline
\end{tabular}

cases where the normal distribution was not followed. The software used was that of SigmaStat 3.5 (Systat Software, Inc.).

\section{Results and discussion}

Characterization of the effluent water derived from the fabric dyeing in textile industry The wastewater samples have, on average, a neutral $\mathrm{pH} 7.0$ at a temperature of $17.6^{\circ} \mathrm{C}$. Their color stood at $740 \mathrm{PCU}$, their COD $1900 \mathrm{mg} / \mathrm{L}$. The turbidity registered was 32 NTU.

Selection of the optimal dosage of ferric chloride $\left(\mathrm{FeCl}_{3}\right)$ as a coagulant and DFJ as a coagulation-flocculation aid Textile wastewaters, unsurprisingly, present high levels of color and, consequently, require considerable quantities of coagulant, in this present case, $\mathrm{FeCl}_{3}$. The optimum dose was determined to be $2000 \mathrm{mg} / \mathrm{L}$ of $\mathrm{FeCl}_{3}$ and $20 \mathrm{mg} / \mathrm{L}$ of DFJ. The high doses of chemical coagulant applied resulted in a reduction in the $\mathrm{pH}$ value and a rise in conductivity. There was a marked reduction in color and turbidity, of about 86 and $79 \%$, respectively, with respect to the untreated water, even for doses as low as $100 \mathrm{mg} / \mathrm{L}$; the optimum dose was observed for $2000 \mathrm{mg} / \mathrm{L}$ of coagulant, with a color and turbidity reduction above 89 and $93 \%$, respectively; however, there was no major change in color and turbidity for those samples with doses between 100 and $1000 \mathrm{mg} / \mathrm{L}$.

The results obtained for the removal of turbidity and color (after the use of $\mathrm{FeCl}_{3}$ alone) are presented in Fig. 3.

As shown in Fig. 4, the removal efficiency of the use of DFJ was measured as the reduction observed with respect to the values attained after the optimum removal without DFJ. These additional removals were over $31 \%$ and over $17 \%$ for color and turbidity, respectively, even for a DFJ dose as low as $20 \mathrm{mg} / \mathrm{L}$.

Treatability tests results Changes in $\mathrm{pH}$ values following the addition of DFJ were negligible for all tests, when compared to the values obtained for the chemical coagulant alone. In addition, although one might expect a further reduction in conductivity on the application of DFJ, given that like color and turbidity, low conductivity is an indicator of water quality, the juice's own high level of

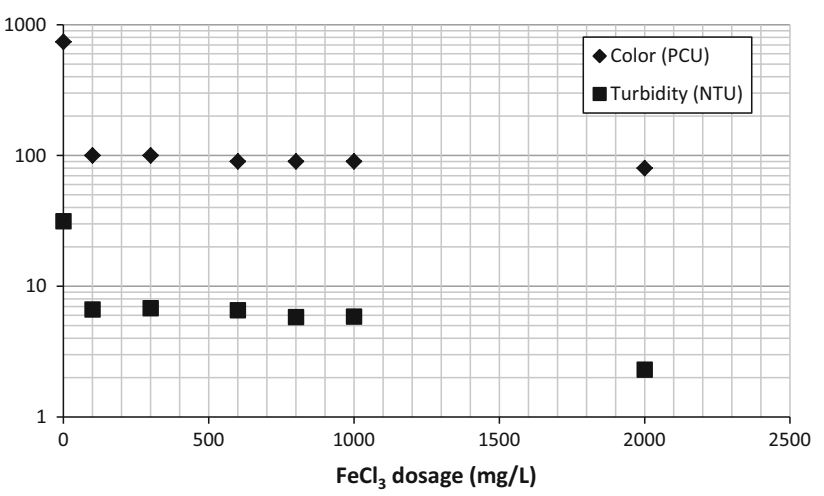

Fig. 3 Mean results for color (PCU) and turbidity (NTU) with single coagulant $\left(\mathrm{FeCl}_{3}\right)$ in treatability tests

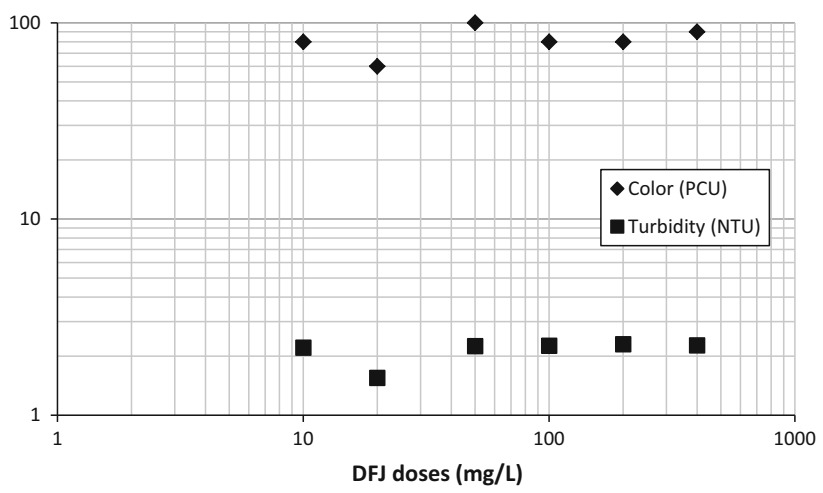

Fig. 4 Mean results for color (PCU) and turbidity (NTU) versus dose of DFJ in combination of the optimal dose of coagulant $(2000 \mathrm{mg} / \mathrm{L}$ $\mathrm{FeCl}_{3}$ )

conductivity means that the final conductivity value is similar to that of raw industrial wastewater.

The most significant result is that the use of DFJ, as a coagulation-flocculation aid, when compared to the chemical coagulant alone, leads to an enhanced reduction, by some $31 \%$, in the values registered for color, as shown

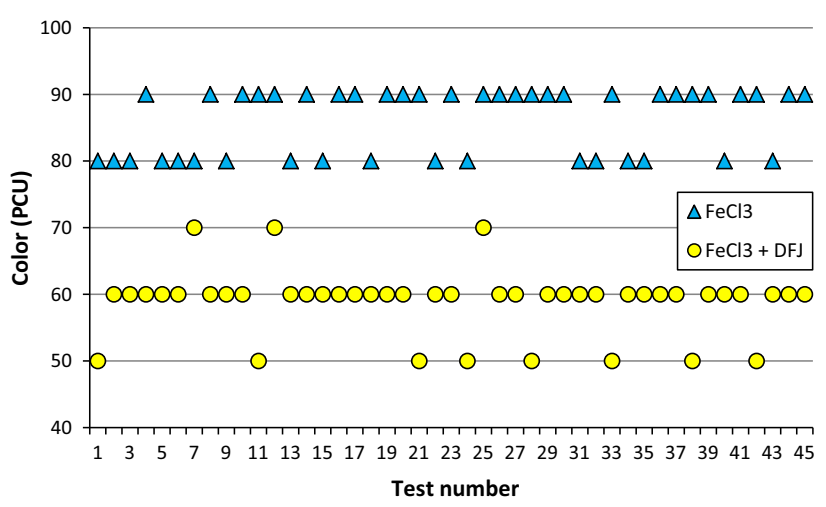

Fig. 5 Results for effluent's color for the chemical coagulant $(2000 \mathrm{mg} / \mathrm{L})$ alone and combined with DFJ $(20 \mathrm{mg} / \mathrm{L})$ 


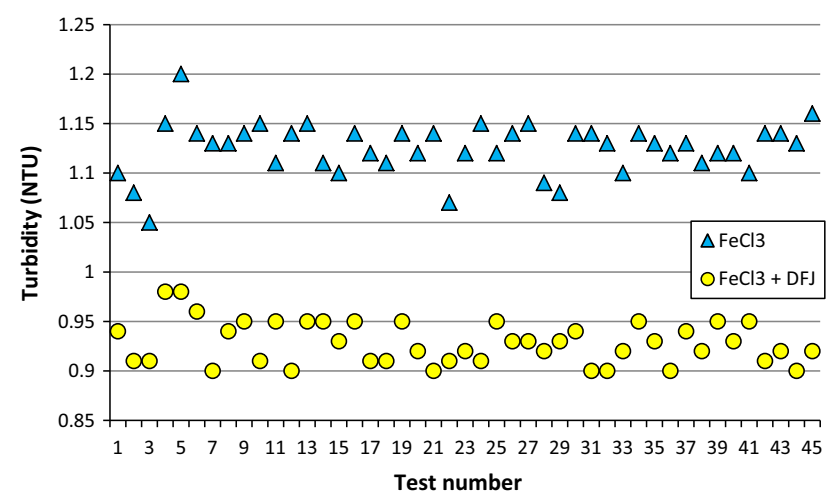

Fig. 6 Results for effluent's turbidity for the chemical coagulant $(2000 \mathrm{mg} / \mathrm{L})$ alone and combined with DFJ $(20 \mathrm{mg} / \mathrm{L})$

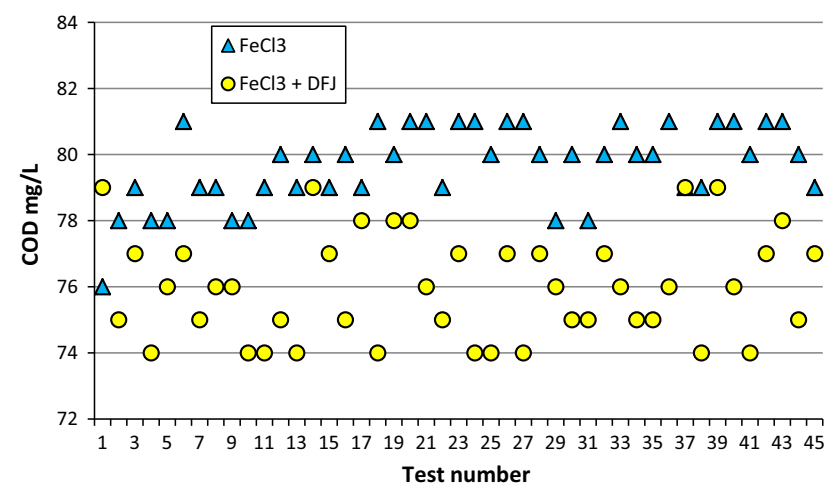

Fig. 7 Results for effluent's COD for the chemical coagulant alone (2000 mg/L) and combined with DFJ (20 mg/L)

in Fig. 5, and $17 \%$ for turbidity (Fig. 6). No significant differences were observed (Fig. 7) in the COD values $(\alpha=0.05 ; P<0.001)$.

The effluents derived from the dyeing processes contain non-biodegradable and dissolved compounds which must be removed via a tertiary treatment because previous biological and physicochemical processes are not able to reach effluent standards (Tabrizi and Mehrvar 2004; Vidal et al. 2004; Rajkumar and Kim 2006; Vilaseca et al. 2010). The results for total color removal with coagulant and DFJ (92\%) are similar to those reported by Fan et al. (2007) who achieved a removal rate of $94 \%$ using a flocculation aid along with coagulant salt.

\section{Conclusion}

The amphiphilic glycosides present in the juice obtained from the leaves of Furcraea sp. and later fermented have shown that they work as a coagulation-flocculation aid that could be used to treat residual waters derived from the fabric dyeing process of the textile industry. The fermentation and separation of the decanted fique juice is a process with two important environmental benefits: First, the contaminating properties of fique juice are significantly reduced via a simple fermentation process, and second, there are potential commercial opportunities for converting it into an industrial wastewater cleaning product. On further investigation, such opportunities may be extended into domestic wastewater treatment.

Acknowledgments The researchers are grateful to the Universidad Piloto de Colombia for the technical and financial support provided with the 22PAGA-2013/14 project and also thank the Universidad Antonio Nariño for providing financial support in 2009 and 2010.

\section{References}

Agudelo N, Hinestroza JP, Husserl J (2015) Removal of sodium and chloride ions from aqueous solutions using fique fibers (Furcraea spp.). Water Sci Technol. doi:10.2166/wst2015593

Arroyave P, Velázquez D (2001) Aprovechamiento integral de Furcraea macrophylla Backer (Comprehensive utilization of Furcraea macrophylla Backer). Universidad EAFIT, Medellín

Casierra-Posada F, Pérez W, Portilla F (2006) Relaciones Hídricas y distribución de materia seca en especies de fique (Furcraea sp. Vent.) cultivadas bajo estrés por $\mathrm{NaCl}$ (Water relations and dry matter in fique species (Furcraea sp. Vent.) cultivated under stress by $\mathrm{NaCl}$ ). Agronomía Colombiana, 24(2):280-289. http:// www.bdigital.unal.edu.co/23255/1/20040-66942-1-PB.pdf

Correia VM, Stephenson T, Judd SJ (1994) Characterization of textile wastewaters-a review. Environ Technol 15(10):917-929. doi:10.1080/09593339409385500

Duque J, González L (1999) Propuesta tecnológica para la producción de un agente tensoactivo biodegradable a partir del jugo del Fique como desecho del proceso de desfibrado (Technological proposal for the production of a biodegradable surfactant from Fique juice as waste pulping process). Facultad de Ingeniería Química, Universidad Pontificia Bolivariana de Medellín, Medellín, Colombia

FINAGRO-Fondo para el financiamiento del sector agropecuario (2013) https://www.finagro.com.co/sites/default/files/node/basicpage/files/fique_-_anuario_2013.pdf. Accessed 18 June 2015

Fan D, Wang L, Wang J (2007) Experimental research on printing and dyeing wastewater treatment through new compound flocculation agent. Huan Jing Ke Xue 28(6):1285-1289

Golob V, Vinder A, Simonic M (2005) Efficiency of the coagulation/ flocculation method for the treatment of dye bath effluents. Dyes Pigments 67(2):93-97. doi:10.1016/j.dyepig.2004.11.003

Gong WJ, Li F, Xi DL (2008) Oxidation of industrial dyeing wastewater by supercritical water oxidation in transpiring-wall reactor. Water Environ Res 80(2):186-192. doi:10.2175/ $106143007 X 221067$

Hood E (1997) From green plants to industrial enzymes in waste treatment. J Chem Technol Biotechnol 69:141-153

Iannacone J, Cajachagua C, Dueñas B, Castillo L, Alvariño L, Argota G (2013a) Agave americana and Furcraea andina (Asparagaceae) on Culex quinquefasciatus (Diptera) and Heleobia cumingii (Mollusca). Neotropical Helminthol 7(2):311-325. http://dialnet.unirioja.es/descarga/articulo/4702111.pdf

Iannacone J, La Torre MI, Flores LA, Cepeda C, Oroya HA, Argota G (2013b) Toxicity of the biopesticides agave americana, Furcraea andina (Asparagaceae) and Sapindus saponaria (Sapindaceae) on invader snail Melanoides tuberculata (Thiaridae). 
Neotropical Helminthol 7(2):231-241. http://dialnet.unirioja.es/ descarga/articulo/4701749.pdf

Khiari R, Dridi-Dhaouadi S, Aguir C, Mhenni MF (2010) Experimental evaluation of eco-friendly flocculants prepared from date palm rachis. J Environ Sci 22(10):1539-1543. doi:10.1016/ S1001-0742(09)60286-2

Longsdon GS, Hess A, Horsley M (1999) Guide to selection of water treatment processes. Chapter 3 in American Water Works Association (Larry Hager). In: Letterman RD (ed) Water quality and treatment. A Handbook of Community Water Supplies, 5th edn. McGraw-Hill (ISBN 0-07-001659-3)

Lozano-Rivas WA (2011) Uso del extracto de fique (Furcraea sp.) como coadyuvante de coagulación en el tratamiento de aguas residuales industriales (Use of fique extract (Furcraea sp.) as coagulant aid in the treatment of industrial wastewaters). Universidad Antonio Nariño, Bogotá

Lozano-Rivas WA (2012) Uso del extracto del fique (Furcraea sp.) como coadyuvante de coagulación en tratamiento de lixiviados [Use of the extract of fique (Furcraea sp.) as coagulant aid in leachate treatment]. Revista Internacional de Contaminación Ambiental 28(3):219-227. http://www.redalyc.org/articulo. oa? $\mathrm{id}=37023183004$

Martínez MA, Pacheco JC (2006) Protocolo para la micropropagación de Furcraea macrophylla Baker (Micropropagation protocol for Furcraea macrophylla Baker). Agronomía Colombiana 24(2):207-213. http://www.redalyc.org/articulo.oa?id=1803162 39002

Meraz KAS, Ponce Vargas SM, Lopez Maldonado JT, Cornejo Bravo JM, Oropeza Guzman MT, Lopez Maldonado EA (2016) Ecofriendly innovation for nejayote coagulation-flocculation process using chitosan: evaluation through zeta potential measurements. Chem Eng J 284:536-542. doi:10.1016/j.cej.2015.09.026

Ministry of Environment, Housing and Territorial Development (MAVDT)—Colombia; Cadena Productiva Nacional del Fique (CADEFIQUE) (2006) Guía ambiental del sub-sector fiquero (Environmental guide of fique subsector). MAVDT y CADEFIQUE, Bogotá D.C. https://www.cortolima.gov.co/SIGAM/ nuevas_guias/fique.pdf

Monje-Ramirez I, Orta de Velásquez MT (2004) Removal and transformation of recalcitrant organic matter from stabilized saline landfill leachates by coagulation-ozonation coupling processes. Water Res 38(9):2359-2367. doi:10.1016/j.watres. 2004.02.011

Ntampou X, Zouboulis AI, Samaras P (2006) Appropriate combination of physico-chemical methods (coagulation/flocculation and ozonation) for the efficient treatment of landfill leachates.
Chemosphere 62(5):722-730. doi:10.1016/j.chemosphere.2005. 04.067

Rajkumar D, Kim JG (2006) Oxidation of various reactive dyes with in situ electro-generated active chlorine for textile dyeing industry wastewater treatment. J Hazard Mater 136(2):203-212. doi:10.1016/j.jhazmat.2005.11.096

Rivas FJ, Beltrán F, Carvalho F, Acedo B, Gimeno O (2004) Stabilized leachates: sequential coagulation-flocculation + chemical oxidation process. $\mathrm{J}$ Hazard Mater 116(1-2):95-102. doi:10.1016/j.jhazmat.2004.07.022

Saritha V, Srinivas N, Vuppala NVS (2015) Analysis and optimization of coagulation and flocculation process. Appl Water Sci. doi:10.1007/s13201-014-0262-y

Soares GMB, Amorim TP, Lageiro M, Costa-Ferreira M (2006) Pilotscale enzymatic decolorization of industrial dyeing process wastewater. Text Res J 76(1):4-11. doi:10.1177/ 0040517506053901

Sungur F, Gülmez F (2015) Determination of metal contents of various fibers used in textile industry by MP-AES. J Spectrosc. doi: $10.1155 / 2015 / 640271$

Tabrizi GB, Mehrvar M (2004) Integration of advanced oxidation technologies and biological processes: recent developments, trends, and advances. J Environ Sci Health A Tox Hazard Subst Environ Eng 39(11-12):3029-3081. doi:10.1081/ESE200034939

Tafesse T, Yetemegne A, Kumar S (2015) The physico-chemical studies of wastewater in Hawassa textile industry. J Environ Anal Chem 2(4):153. doi:10.4172/2380-2391.1000153

Tatsi A, Zouboulis A, Matis K, Samaras P (2003) Coagulationflocculation pretreatment of sanitary landfill leachates. Chemosphere 53(7):737-744. doi:10.1016/S0045-6535(03)00513-7

Universidad Jorge Tadeo Lozano and FENALFIQUE (2014) Fique una historia con futuro (Fique: a story with a future). http://www. utadeo.edu.co/es/noticia/destacadas/home/1/fique-una-historiacon-futuro. Accessed 18 June 2015

Vidal G, Nieto J, Cooman K, Gajardo M, Bornhardt C (2004) Unhairing effluents treated by an activated sludge system. J Hazard Mater 112(1-2):143-149. doi:10.1016/j.jhazmat.2004. 04.004

Vilaseca M, Gutiérrez MC, López-Grimau V, López-Mesas M, Crespi M (2010) Biological treatment of a textile effluent after electrochemical oxidation of reactive dyes. Water Environ Res 82(2):176-182. doi:10.2175/106143009X447902

Zheng X, Liu J (2006) Dyeing and printing wastewater treatment using a membrane bioreactor with a gravity drain. Desalination 190(1-3):277-286. doi:10.1016/j.desal.2005.09.008 